\title{
El ser del hombre es su eticidad
}

\author{
Ramón Xirau
}

$\mathrm{E}$

1 pensamiento de Juliana González se ha revelado tanto en sus cátedras - principalmente seminarios de Metafísica y de Ética-como en su obra escrita, ya muy amplia y muy suya, personal. Recordemos sus principales libros. Después de su tesis sobre Eduardo Nicol, su maestro, ha publicado sucesivamente los siguientes libros: El malestar en la moral. Freud y la crisis de la ética (1986), Ética y libertad (1989) y El héroe en el alma. Tres ensayos sobre Nietzsche (1993), libro breve, hondo y, ¿por qué no decirlo?, hermoso. Ahora, apenas dos años después de la aparición de este Nietzsche, $E l$ ethos, destino del hombre que ahora me ocupa. Antes, sin embargo, dos observaciones.

El conocimiento filosófico de Juliana González es, como es sabido, muy amplio. Va de los clásicos a los modernos y a los que suele llamarse posmodernos -término, por cierto, muy impreciso. Entre los clásicos hay que recordar sus estudios sobre Platón, la presencia muy constante de Heráclito -el título del presente libro "traduce" a Heráclito de manera original, muestra del verdadero conocimiento de la lengua griega. Entre los modernos y contemporáneos tal vez debemos mencionar principalmente a Nietzsche, Freud y Heidegger, cuyas obras la doctora González conoce a fondo al vincularlas con lo que es central en su pensamiento: la ética, una ética muy ligada -habremos de verloa la ontología.

Segunda observación. En El ethos, destino del hombre se ocupa de lo que se llama "ética aplicada". No se habla aquí de manera directa de los problemas que plantea la biología genética y en especial de la ingeniería genética, problemas, por cierto, de orden moral. Son varias las ideas de Juliana González que implican una teoría del valor, de los valores éticos relacionados con la medicina. Lo ha mostrado en repetidas ocasiones en sus frecuentes participaciones en coloquios como el que se celebra anualmente en el Hospital de Nutrición Salvador Zubirán. En el fondo, para ella se trata de restaurar un 
nuevo humanismo, de fundamentar principios que tengan en cuenta lo humano, lo auténticamente humano.

Vuelvo a la parte teórica, teórico-práctica de $E l$ ethos, destino del hombre, este ethos que es nuestro destino como seres humanos. Hay que repetirlo. Escribe Juliana González, en su traducción de Heráclito, que el ethos es, en efecto, nuestro destino. En todo lo que ella escribe está presente esta versión de Heráclito, siempre que se recuerde, y esto es crucial, que en su teoría confluyen ética y ontología, teoría del valor y teoría del ser.

Crucial para el pensamiento de nuestra autora es lo que aparece ya desde el inicio del libro cuando se precisa el sentido del humanismo. En busca de lo humano y del humanismo, Juliana González recuerda la "movilidad" del hombre. Esta movilidad no es "indiferente" para la vida humana y para sus "posibilidades existenciales". En efecto, el hombre puede humanizarse o deshumanizarse. Su movimiento, en este sentido, es movimiento moral y conlleva diversos modos y grados de ser en los que precisamente cabe hablar de lo "humano" versus lo "inhumano". El movimiento de que se trata es de "ascenso" o "descenso" en la escala del ser, inseparable de la del "bien" y del "mal". Sin embargo, hay que ir más a fondo. Así, la también autora de $L a$ metafísica dialéctica de Eduardo Nicol modifica, inmediatamente, lo que acaba de enunciar. Para ello remite a Platón y especialmente al mito del cochero. Pues bien, este mito del Fedro, diálogo tan bien analizado en el presente libro de Juliana González, es la afirmación de la naturaleza "alada" del hombre. Lo propiamente humano es la capacidad de trascender las "ambigüedades" y las "alternativas". ¿Qué es entonces lo humano? Es, sin duda, la virtus latina, la areté griega. Ser hombre es así, "humanización constante" en un proceso activo, no en un estado fijo, uniforme e inmutable. Es decir, y citando a Nicol citado por Juliana González, ser humano significa "adquisición y retención de la autenticidad". Y lo humano del hombre es su ethos, es decir, su "carácter" puesto que el "carácter es para el hombre su destino."

¿Temible el daimon griego? Puede serlo, pero es también "genio bienhechor" que, en última instancia, remite a la eu-daimonia, es decir, a la felicidad.

$\mathrm{Y}$, ¿los valores?, ¿qué sucede con los valores? Por una parte los hombres, seres temporales que ex-sisten, que están situados en el cambio y frecuentemente en la alteración. Así vistos, los valores serían puramente situacionales. Pero nada de esto significa que los valores no sean también universales, "tampoco el tiempo y la diversidad situacional ocurre fuera del ser y la universalidad".

La última parte del libro remite a Heidegger y a su relación con el humanismo. A mi modo de ver hay algo de malsano en el llamado humanismo de Heidegger. La actitud de Sartre es más sana que la de Heidegger, este Heidegger es para mí especialmente nebuloso en la Carta sobre el humanismo. Pero lo 
importante de este libro reciente de Juliana González es su defensa muy exacta y puntual de lo que se llamó, desde la patrística, y claro, desde Pico della Mirandola, la "dignidad del hombre". Una defensa, en efecto tanto de la universalidad como de la autonomía de los valores de la persona humana, y una defensa radical, esto cuando sabemos que el hombre es en su ser, destino, cuando sabemos que el ser del hombre es su eticidad y que ésta habita en su ser. 